\title{
Dung beetles (Coleoptera: Scarabaeoidea) in three landscapes in Mato Grosso do Sul, Brazil
}

\author{
Rodrigues, MM. ${ }^{a *}$, Uchôa, MA. ${ }^{a}$ and Ide, S. ${ }^{b}$ \\ ${ }^{\text {a}}$ Laboratório de Insetos Frugívoros, Faculdade de Ciências Biológicas e Ambientais - FCBA, \\ Universidade Federal da Grande Dourados - UFGD, CP 241, CEP 79804-970, Dourados, MS, Brazil \\ 'Instituto Biológico de São Paulo, Av. Conselheiro Rodrigues Alves, 1252, \\ CEP 04014-002, Vila Mariana, São Paulo, SP, Brazil \\ *e-mail: marinomiloca@yahoo.com.br
}

Received February 7, 2012 - Accepted September 10, 2012 - Distributed February 28, 2013

\begin{abstract}
Dung beetles (Coleoptera: Scarabaeoidea) in three landscapes in Mato Grosso do Sul, Brazil. Dung Beetles are important for biological control of intestinal worms and dipterans of economic importance to cattle, because they feed and breed in dung, killing parasites inside it. They are also very useful as bioindicators of species diversity in agricultural or natural environments. The aims of this paper were to study the species richness, and abundance of dung beetles, helping to answer the question: are there differences in the patterns of dung beetle diversity in three environments (pasture, agriculture and forest) in the municipality of Dourados, in the state of Mato Grosso do Sul. A total of 105 samplings were carried out weekly, from November 2005 to November 2007, using three pitfall traps in each environment. The traps were baited with fresh bovine dung, and 44,355 adult dung beetles from 54 species were captured: two from Hyborosidae and 52 from Scarabaeidae. Five species were constant, very abundant and dominant on the pasture, two in the agricultural environment, and two in the environment of Semideciduous forest. Most of the species were characterised as accessories, common and not-dominant. The species with higher abundance was Ataenius platensis Blanchard, 1844. The indexes of Shannon-Wiener diversity were: 2.90 in the pasture, 2.84 in the agricultural environment and 2.66 in the area of native forest. The medium positive presence of dung beetles in the traps in each environment were: $36.88,42.73$ and 20.18 individuals per trap, in the pasture, agricultural environment and in the native forest, respectively. The pasture environment presented a higher diversity index. The species diversity of dung beetles was superior where there was higher abundance and regularity of resource (bovine dung).
\end{abstract}

Keywords: biodiversity, Coleoptera, Hybosoridae, Scarabaeidae, population ecology.

\section{Besouros coprófagos (Coleoptera: Scarabaeoidea) em três paisagens de Mato Grosso do Sul, Brasil}

\begin{abstract}
Resumo
Coleópteros coprófagos são importantes (especialmente Scarabaeidae) para controle biológico de vermes gastrointestinais e de dípteros; dessa forma, são de importância econômica para a pecuária, pois esses besouros utilizam excrementos como alimento e sítio para reprodução. Eles são também de grande utilidade como bioindicadores da diversidade. $\mathrm{O}$ objetivo deste trabalho foi avaliar a riqueza em espécies e a abundância de besouros coprófagos, além de verificar se estes atributos são diferentes nos três ambientes (pastagem, agricultura e mata), no município de Dourados-MS. Foram realizadas 105 avaliações semanais, de novembro de 2005 a novembro de 2007, utilizando-se três armadilhas "pitfall" em cada ambiente. Estas foram iscadas com fezes frescas de bovinos. Foram coletados 44.355 adultos de 54 espécies: duas de Hyborosidae e 52 de Scarabaeidae. Cinco espécies foram constantes, muito abundantes e dominantes na pastagem, duas na área agrícola e duas na mata. A maioria das espécies foi considerada acessória, comum e não dominante. A espécie que apresentou maior abundância foi Ataenius platensis Blanchard, 1844. Os índices de diversidade de Shannon-Wiener foram: 2,90, na pastagem; 2,84, na área agrícola, e 2,66, na mata. A presença média de coleópteros coprófagos nas armadilhas positivas nos três ambientes, em indivíduos por armadilha, foi 36,88 (pastagem), 42,73 (área agrícola) e 20,18 (mata). O ambiente de pastagem apresentou maior índice de diversidade. A diversidade foi maior onde houve maior abundância e regularidade de alimentos.
\end{abstract}

Palavras-chave: biodiversidade, Coleoptera, Hybosoridae, Scarabaeidae, ecologia populacional. 


\section{Introduction}

Anthropogenic changes on natural environments, reducing native forests in small fragments of various sizes, shapes, and conversion of the land from human activities are the main causes of climate changes, and of losses in biodiversity (Quintero and Roslin, 2005). In some regions in Brazil, this conversion and fragmentation are quite obvious. The fragments of natural areas are landscapes that were anthropised by conversion into agriculture and pasture (Favero et al., 2011). The first occupation was a consequence of deforestation to feed cattle with pasture, and for agricultural use, converting the native forests into open fields, causing changes in the structure of the local fauna (mainly excluding great autochthonous mammalians), due to the reduction of niches and habitats (Ganho and Marinoni, 2005) in natural ecosystems.

Modification and fragmentation of natural areas are the two most common types of conversions of landscapes. In general, studies have detected predictable responses in relation to the fragmentation of forests. The diversity tends to be reduced when natural areas are converted into areas to install crops (Nichols et al., 2007). The replacement of native flora by large areas of pasture and agriculture has caused environmental disturbances. The reduction of natural areas has led to biodiversity loss, leading to loss of genetic variability of the remaining species. Large deforested areas serve as barriers avoiding connectivity between forest fragments (Hernández et al., 2003). These regions became a landscape in mosaic, leaving few areas of forest required for preservation, such as small clumps remaining in pasture areas for shading, and riparian areas, for the preservation of water courses and springs. It is still necessary to understand the responses of insects to changes in the landscape, since there is little information about which taxons are able to remain in altered environments. It is known that the insects are very sensitive to environmental changes (Andersen, 2003), and dung beetles are of great importance in maintaining ecosystem functions. Scarabaeoidea plays an important role in interactions with other animals, especially mammals, because they use animal feces as a resource to breed and live in. So, these beetles have been used as bioindicators of environmental quality in tropical forests (Halffter and Favila, 1993) and savannas.

Dung beetles (Scarabaeoidea) are very rich in species in the neotropics, especially in forests and savannas. In addition, these beetles represent a well-defined community in terms of taxonomy, functionality (Hanski and Cambefort, 1991) and ecology, with specific behaviour (Halffter, 1991). They are among the scavengers with greater efficiency and agility in decomposition and cycling of organic matter, also serving as food resources for several other groups of animals. Because dung beetles feed, nest and breed specially in the feces of vertebrates, they promote the disintegration and decomposition of fecal masses, and thus contribute with soil enrichment, as well as to help in the biocontrol of gastrointestinal worms, and insects harmful to livestock, such as the Horn Fly, Haematobia irritans (Linnaeus, 1758) (Rodrigues and Marchini, 2000). The attributes of the community of dung beetles, such as species richness, abundance, constancy and dominance could be related to the degree of alteration of the landscape, but also with the adaptability of these beetles to the environments. In those ecosystems there are significant differences in vegetation that attract small mammals, birds, and consequently Scarabaeoidea, looking for their feces (Nichols et al., 2007).

Among the environmental factors that influence the populations of dung beetles, the type of vegetation is one of the most important (Halffter, 1991). In some environments, it is possible to see differences in the abundance and biomass of beetles in open areas, compared with forests (Lumaret and Kirk, 1987). However, the presence and permanence of Scarabaeoidea in different environments are related to several other factors (Ridsdill-Smith, 1986), because this community has demonstrated sensitivity to changes imposed on the environment (Durães et al., 2005).

Few studies in the Neotropics have evaluated the response of Coleoptera to environmental changes, and there is little information about the conversion of the Cerrado areas in grazing ecosystems, and in some areas of pasture still lack information about the community of dung beetles. So, in this research we assessed the community of dung beetles in three areas in Mato Grosso do Sul state, marked by a few forest fragments immersed in a wide array of crops and livestock. The main question in this paper is: Are the community attributes, such as species richness and abundance, different for each location? Our hypothesis is that the pasture area is the richest in dung beetles species, and that the species composition of the communities would be different in each surveyed area.

\section{Material and Methods}

\subsection{Experimental area}

The grazing environment ( $21^{\circ} 59^{\prime} 24^{\prime}$ S, $55^{\circ} 19^{\prime} 21.2^{\prime \prime}$ W, $420 \mathrm{~m}$ ), about $75 \mathrm{~km}$ from Dourados-MS, with $22 \mathrm{ha}$ of the grass Brachiaria sp. (Poaceae), is part of a total area rural of 4,800 ha destined to a settlement for family agriculture. This environment is surrounded by a dense wooded savanna formation, and the soil is a dystrophic red latosol of medium texture (Brasil, 1982).

The agricultural environment $\left(22^{\circ} 08^{\prime} 40.2^{\prime \prime} \mathrm{S}, 55^{\circ}\right.$ 01' 33.7" W, $447 \mathrm{~m}$ ) is $40 \mathrm{~km}$ from Dourados, at about $35 \mathrm{~km}$ from the pasture area, and $20 \mathrm{~km}$ from the area of forest. A total area of 2.470 ha is occupied annually with soybean and corn in summer, but with wheat in the winter. In this area there are some capons and natural preservation areas with swamps, springs and riparian vegetation that accompany small streams. The vegetation is similar to that of pasture area, but with dystrophic red latosol (Brasil, 1982).

The forest environment (22 59' 24.9' S, 54 54' 56.2" $\mathrm{W}, 434 \mathrm{~m}$ ) is about $43 \mathrm{ha}$, and about $15 \mathrm{~km}$ from Dourados. This is an area of environmental reserve, bordered by 
pasture. The type of vegetation is tropical semideciduous forest, a remnant of the Atlantic Forest in Dourados. The soil type is hapludox, clayey, and the climate according to the international classification by Köppen is humid mesothermal, Cwa type (Brasil, 1982).

Sampling: The study of the fauna of dung beetles (Scarabaeidae) in Dourados was performed by weekly sampling with pitfall traps (Flechtmann et al., 1995), at which were exchanged baits of traps, for two consecutive years (from November 2005 to November 2007). There were a total of 105 samples in each of the three environments. Three pitfall traps were used in each environment. They were baited with $(300 \mathrm{~g})$ fresh bovine fecal mass in each trap (Koller et al., 2007), and they were installed at a minimum distance of $200 \mathrm{~m}$ from each other.

The sampled beetles were kept in bottles with $70 \%$ ethanol. The specimens after being mounted on entomological pins, labelled, were sent to the Instituto Biológico de São Paulo, São Paulo, Brazil, where they were identified by Dr. Sérgio Ide. After that, the beetles were deposited in the Museu da Biodiversidade of the Universidade Federal da Grande Dourados (UFGD), Dourados, Mato Grosso do Sul state, Brazil.

\subsection{Data analysis}

In the faunal analysis, we calculated the abundance (A), constancy (C) and dominance (D) for the species in the three environments, using the Software by Hammer et al. (2003). For purposes of the calculation, both male and female specimens were included.

The diversity of species in the three ecosystems was calculated by the Shannon-Wiener (H') Diversity Index. That index measures the degree of uncertainty in predicting to which species an individual belongs, sampled at random and picked at random from a population with $\mathrm{N}$ individuals and S species (Colwell, 2003).The higher the ShannonWiener index is, the greater is the species diversity of the site under study (Krebs, 1978; Magurran, 1988).

To compare the abundances in the three environments, the mean abundance of individuals of all individuals collected by positive traps (the traps that had captured at least one individual) was calculated. The standard deviation was calculated and the non-parametric Mann-Whitney (U) test was applied, using the Software by Ayres et al. (2007) to detect differences or not between populations of the three environments.

\section{Results}

\subsection{Species richness and abundance}

In the three surveyed areas 44,355 individuals of the coprophagous Scarabaeoidea were collected, represented by 54 species, being 52 of Scarabaeidae (44,221 individuals [99.69\%]) in 19 genera and two subfamilies (Scarabaeinae and Aphodiinae), and two species of Coilodes Westwood (1845), with 134 individuals $(0.31 \%)$ from Hybosorinae (Hybosoridae) (Table 1).
The greater abundance and species richness were recorded in the area of agriculture, with 41 species and a total of 25,871 individuals, representing $58.32 \%$ of all sampled Scarabaeoidea. The areas of pasture and forest presented similar species richness, with 39 species in each environment (Table 1). However, the abundance and species composition differed, being higher in the area of pasture, with 13,138 specimens, representing $29.62 \%$ of all collected specimens. In the forest environment 5,346 Scarabaeidae were captured, representing $12.05 \%$ of the total. Forty five of the collected specimens were identified until species, but nine, due to the lack of taxonomic studies for Brazilian fauna, until the level of genus. The richest genus in species was Dichotomius Hope (1838), with nine species, and the most abundant species was Ataenius platensis, with 20,815 individuals (Table 1).

\subsection{Species composition}

Dichotomius (Selenocopris) ascanius (Harold, 1869), and Canthon sp.2 occurred only in the area of pasture; Canthidium sulcatum (Perty, 1830), Deltochilum (Hybomidium) icarus (Olivier, 1789), and Gromphas lacordairei Brull (1834) only in the agriculture environment; and seven species: Canthidium dispar Harold, 1867, Canthidium sp.2, Canthon conformist Harold, 1868, Canthon (Glaphyrocanthon) oliverioi (Pereira \& Martínez, 1956), Canthon quinquemaculatus Laporte, 1841, Coilodes humeralis (Mannerhein, 1829), and Dichotomius (Dichotomius) sp1., occurred only in the environment of forest. Seven species occurred simultaneously in the pasture and agriculture environments: Dichotomius (Luederwaldtinia) glaucus (Harold, 1869), Ontherus (Ontherus) digitatus Harold, 1868, Coprophanaeus (Metallophanaeus) sp.1, Aphodius (Blackburnium) lexepunctatus Schimidt, 1911, Aphodius (Nialus) nigritus (Fabricius, 1801), Aphodius (Labarrus) pseudolividus (Balthasar, 1941) and Ataenius sculptilis Harold, 1869. Two species [Onthophagus (Onthophagus) catharinensis Paulian, 1936, and Coilodes sp.1] co-occurred in the pasture and forest environments. Three species [Anomiopus virescens Westwood, 1842, Canthidium sp.2, and Canthom (Canthon) sp.1] cohabited the agricultural and forest environments, but 27 species occurred simultaneously in the three environments (Table 1).

Four species could be considered rare in the region, because they were represented by only one specimen during all the sampling period. These species were: $C$. sulcatum, G. locardairei, and Dichotomius sp1. in the agriculture area, and Dichotomius ascanius piceus in the forest environment (Table 1).

\subsection{Population patterns of the community}

In the pasture, nine species $(23.07 \%)$ were dominant (s), eight (20.51\%) were considered constant (w), three (7.69\%) accessory (y), 28 (71.79\%) accidental (z), 34 species $(87.17 \%)$ were common (c), five $(12.82 \%)$ was very abundant (ma), and 30 species $(76.92 \%)$ were nondominant (n). In this area there were no rare species (r), dispersed (d) neither abundant (a) ones (Table 1). 
Rodrigues, MM., Uchôa, MA. and Ide, S.

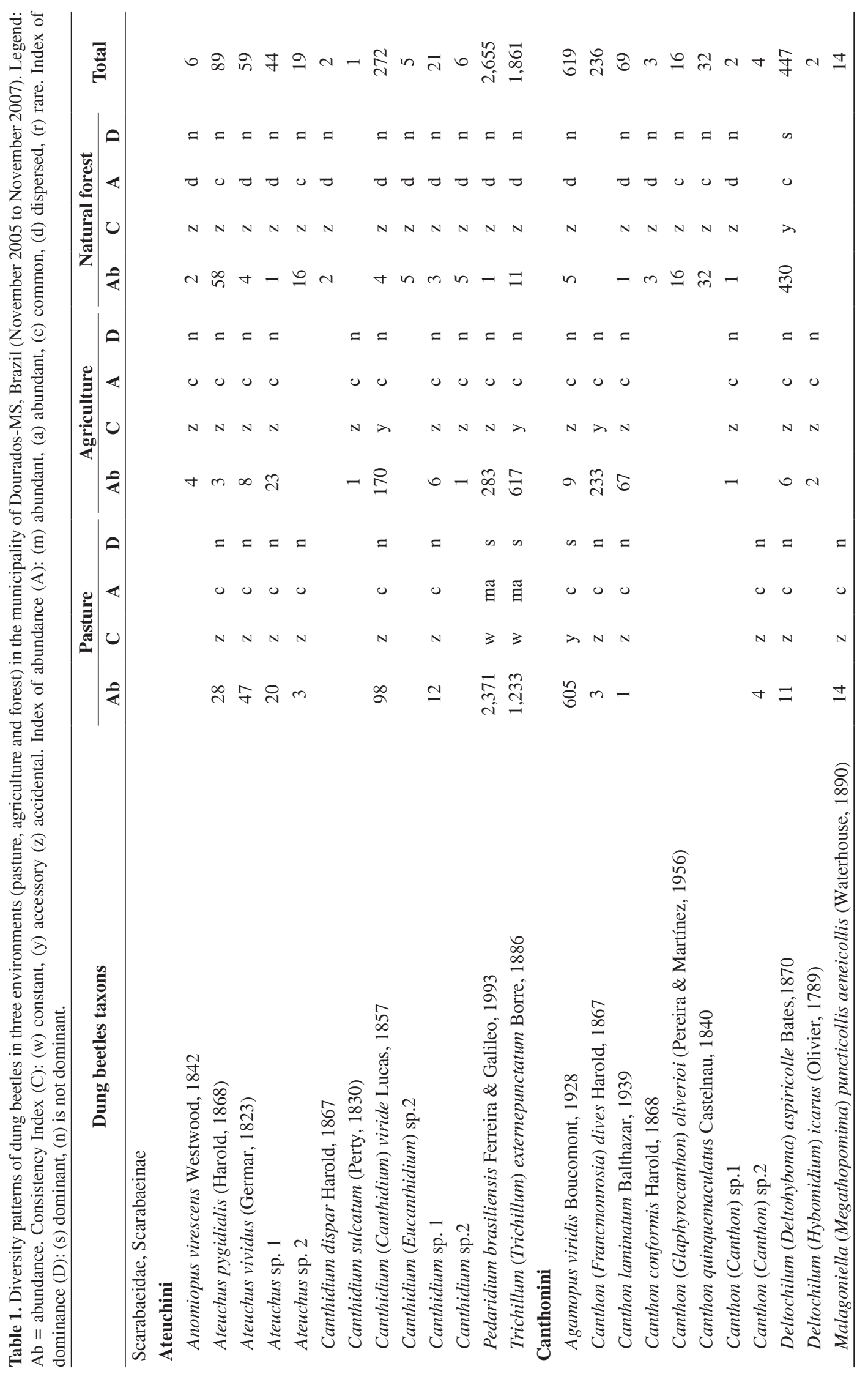




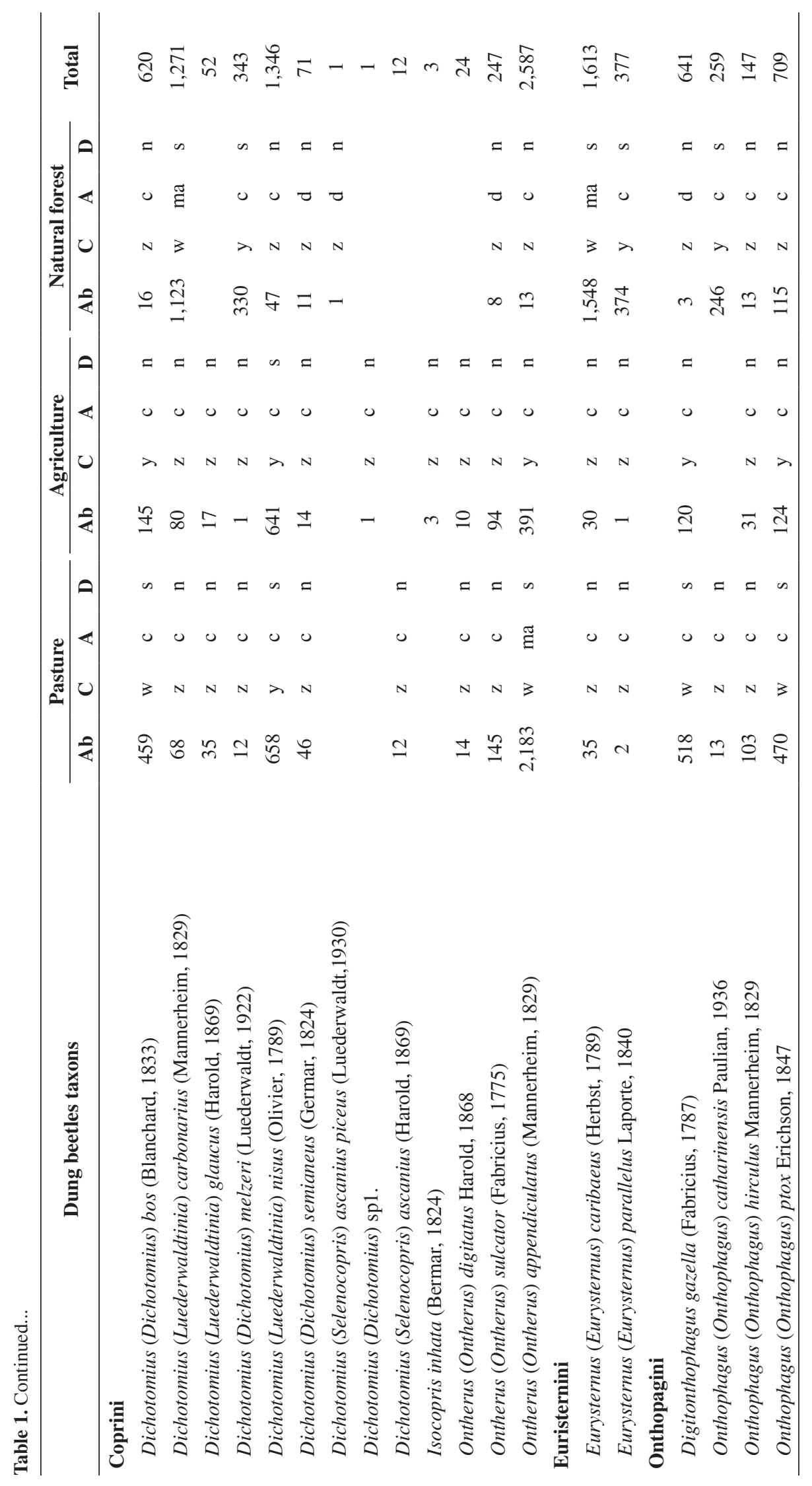


Rodrigues, MM., Uchôa, MA. and Ide, S.

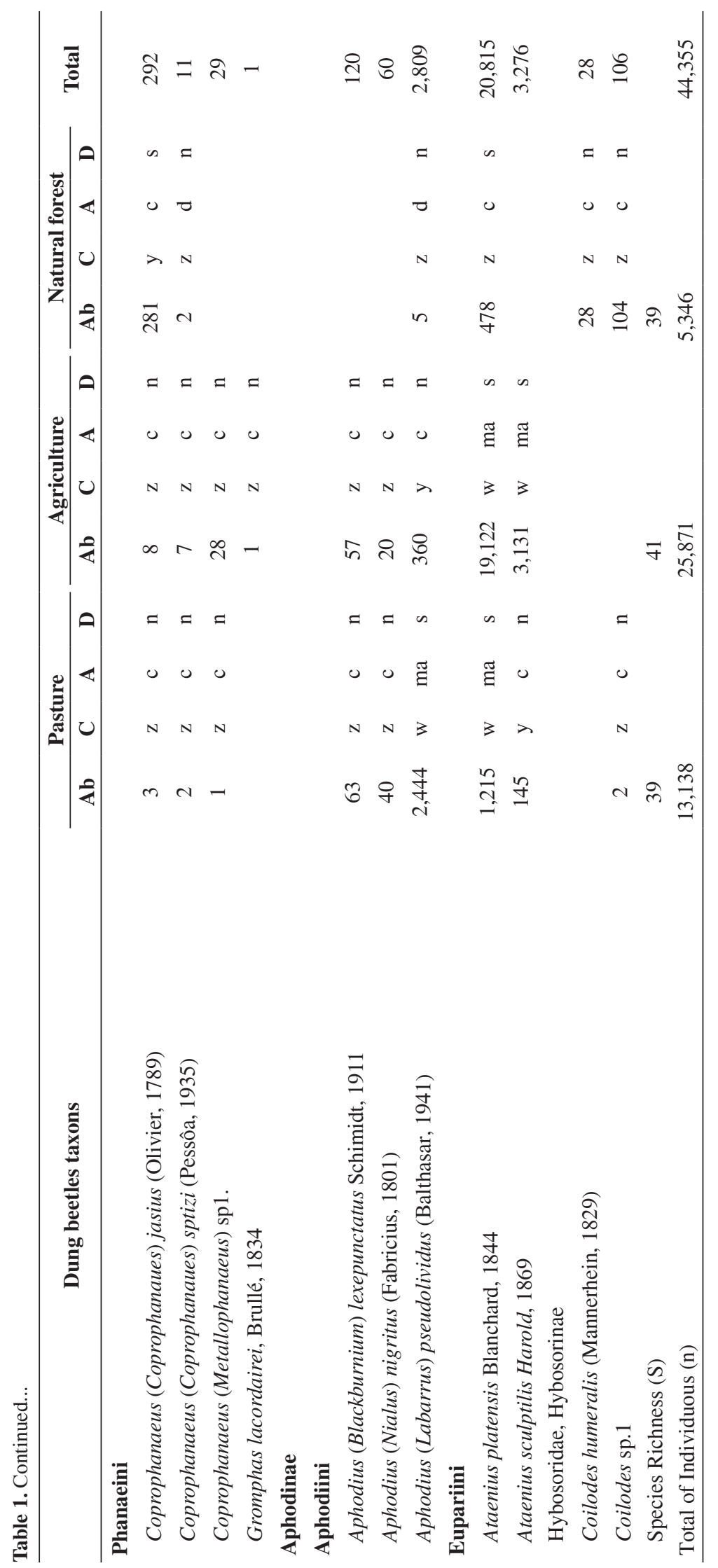


In the area of agriculture, three species $(7.31 \%)$ were found as dominant(s), two species $(4.87 \%)$ were constant (w), nine $(21.95 \%)$ were accessory $(y), 30(73,17 \%)$ were accidental (z), 39 species $(95.12 \%)$ were common (c), two (4.87\%) very abundant (ma), while 38 (73.17) were characterised as non-dominant (n). In this area rare species did not occur (are), dispersed (d), neither abundant (a) (Table 1).

In the forest environment, six species $(15.38 \%)$ were dominant (s), two species (5.12\%) were constant (w), five (12.82\%) were incidental (y), 34 (87.17\%) accidental (z), 20 species $(51.28 \%)$ were dispersed (d), 17 (43.58\%) were common (c), two (5.12\%) were very abundant (ma), and $35(89.74 \%)$ non-dominant (n) (Table 1).

The species considered constant (w), abundant (m), and dominant (s) were: A. pseudolividus (18.60\%), Pedaridium brasiliensis (18.04\%), Ontherus appendiculatus (16.61\%), Trichillum externepunctatum (9.38\%), and A. platensis $(9.24 \%)$ in the pasture; A. platensis $(73.91 \%)$ and Ataenius sculptilis Harold (12.11\%), in the agriculture area Eurysternus caribaeus (Herbst, 1840) (28.95\%), and Dichotomius carbornarius (Mannerheim, 1829) (21\%) in the forest area. A. platensis was the species with the highest abundance among the three studied environments, being recorded greater abundance in the area of agriculture (Table 1).

The Shannon-Wiener diversity index (H') was higher in the pasture environment (2.90), followed by the agriculture area (2.84), and forest (2.66). The pasture and agriculture areas did not differ significantly from each other, and in the forest the abundance was lowest, in relation to other environments (Table 2).

\section{Discussion}

Coprophagous Coleoptera have been considered as sensitive animals to the conversion, modification, reduction and fragmentation of tropical forests. These beetles can be used as bioindicators of forest quality in future. There are studies indicating that part of the original biodiversity of Scarabaeoidea can persist within disturbed landscapes (Nichols et al., 2007). Even in agricultural areas where the degree of degradation reaches alarming proportions, these areas serve to keep a part of the community of dung beetles,

Table 2. Number of positive traps, average number of dung beetle caught in positive traps in the three sampled environments, and standard deviation (Dourados-MS, Brazil, from November 2005 to November 2007).

\begin{tabular}{lccc}
\hline & $\mathbf{N}$ & Means & Standard deviation \\
\hline Pasture & 138 & $36.88^{\mathrm{a}}$ & 44.417 \\
Agriculture & 127 & $42.73^{\mathrm{a}}$ & 57.788 \\
Forest & 126 & $20.18^{\mathrm{b}}$ & 23.551 \\
Total & 391 & 33.40 & 45.153
\end{tabular}

$\mathrm{N}=$ number of positive traps. Different letters in columns indicate significant difference of means test for multiple comparisons by the Mann-Whitney $\mathrm{U}, \mathrm{p}<0.05$. being important for the maintenance and connectivity of the current landscape as a whole (Hernández et al., 2003).

The agricultural environment had higher species richness and greater abundance of individuals in relation to areas of pasture and forest. This greater abundance of the area with agriculture was mainly due to the massive capture of A. platensis. This species was constant, abundant and dominant in two of the three studied areas (pasture and agriculture), and in the agriculture area the number of individuals collected was far superior to that of the two other areas. A. platensis is a multivoltine species, with a high biotic potential, short life cycle (Flechtmann et al., 1995), and colonises more dehydrated fecal masses, differently from other species with habits of burying fresh fecal masses (with high moisture content). This behaviour of A. platensis makes their nesting and establishment in anthropised areas easy. This species may come later to the fecal masses, from which other species have buried part of the material. Otherwise, the adults of A. platensis could be buried along with the feces by species that bury the fecal pellets still fresh.

The fact that other species of Scarabaeidae have the behaviour of burying fresh feces can result in decreased resources for $A$. platensis. It is also likely that the high abundance of $A$. platensis in the agriculture area has been driven by interspecific competition in this environment. This could oblige the species to migrate to other places to search for fecal masses. In addition, there was more supply from cow dung in the pasture. Therefore, traps installed there, were not the only sources of resource that attracted dung beetles, while in the area with agriculture, as the resource (cattle dung) is less abundant, the traps played a stronger role in the attraction of Scarabaeoidea. So, because of its high prolificacy, and ability to migrate in search for resources, A. platensis had the highest abundance in the environment with agriculture.

Due to the greater availability of resources, it was expected that a higher abundance of beetles in the pasture area $(n=13,138)$ would be collected, but this pattern did not happen. In the area with agriculture, almost double the amount of individuals ( $\mathrm{n}=25,871$ ) was found, compared to pasture. On the other hand, in the forest only 5,346 adults of Scarabaeoidea were sampled. Considering the amount of resource available for the beetles, one would expect significant differences both regarding species richness and abundance. In all three environments the difference in species richness was smaller; however, abundance was higher in the area with agriculture (Table 1).

A. platensis in the agricultural environment presented a pattern of population similar to that of species that colonize open and very anthropized habitats, which have as a consequence hyperabundant population with low diversity. Such species, generally, have light body mass, as pointed out by Nichols et al. (2007). Thus, modification, fragmentation of the environment and the type of land use, can modify the response of dung beetles, influencing the colonization strategy of some species in these areas. 
In the forest, there were only small mammals and birds; consequently there was less supply of feces (resource) for dung beetles. Therefore, in the forest was expected to have lower abundance of Scarabaeoidea, and this pattern was confirmed by the results.

In the pasture there were found a greater number of species very abundant and dominant in relation to the other areas. Only A. platensis occurred simultaneously in the areas of pasture and agriculture (Table 1). It was observed that in each environment there are few species with this population pattern. This suggests that highly abundant species may already be adapted to open environments. Because these environments are undergoing constant changes this can affect the community of Scarabaeoidea, as reported by Endres et al. (2007). Different environmental conditions induce a distinctive fauna, mainly by the type of vegetation and existing resource (Ganho and Marinoni, 2005).

In this work, many species occurred simultaneously in the three environments. Probably the individuals of the species with this pattern of occurrence, although they are more adapted to a particular environment, they foraged for resource in the other two environments. In a recent study, Nichols et al. (2007) compared communities of dung beetles in modified forests, environments with recent reforestation, older forested areas, agricultural areas and intact forests. They found rich communities on those sites, with some species typical of native forests, while in agricultural areas they recorded some rare species, and few species were typical of forests.

The behavioral differences of each species, and the environmental characteristics should be considered to have more precise information of the reasons why the species predominate in a given location. Vulinec (2002) notes that negative impacts of habitat modification can be clearly reflected in the changing landscape of late, when it presents in terms of declining species richness and abundance of individuals. In that study, it was found that after a number of years of initial perturbations in certain areas, the community of dung beetles increased again. This increase in species richness and abundance of Scarabaeidae in disturbed areas may be the result of migration of species from habitats of the nearby, such as in vegetation remnants, like was also observed in forested areas by Malva et al. (2009).

In this study, most of the species were considered incidental, common and non-dominant. In all three environments the community of dung beetles showed a large number of species with few individuals, and many individuals belonging to few species. Similar results were obtained for Scarabaeoidea in communities of Neotropics (Hugher, 1999), and in areas cultured with pasture (Koller et al., 2007).

The type of environment has little influence on species richness: agricultural area $(S=41)$, pasture $(S=39)$ and forest $(\mathrm{S}=39)$, but the abundances were different: pasture $(\mathrm{n}=13,138)$, agricultural area $(\mathrm{n}=25,871)$, and forest $(n=5,346)$. However, except for A. platensis, this influence can be seen in the composition of dominant and very abundant species, in relation to the provision of resources (animal feces), with notable influence on abundance (Table 1). Thus, it is likely that the diversity between the three areas was dependent on the amount and regularity in the occurrence of resources, and the structure of the environment (Marinoni and Ganho, 2006). For this reason, data about diversity are important for comparisons between ecosystems. For many species whose functions in the environment are yet unknown, they could be playing important roles in these sites, because they are frequently found in these areas looking for resources. Probably, in open environments such as pastures, the fecal masses quickly suffer dryness at certain seasons, making the action of the adults of these beetles in the burial of feces more difficult. In this case, species such as A. platensis and A. pseudolividus, which were more abundant, play an important role in the disintegration of fecal masses in certain seasons, which may facilitate the action of other organisms in this task.

In a general way, we found that in the three studied environments, there occurred few dominant, constant, and abundant species. This pattern could be related to the presence of few species adapted to that environment, or could be due to the interspecific competition, or that the species are still under the strong influence of human disturbance to the environment, as pointed out by Horgan and Fuentes (2005).

In the area with agriculture there was little supply of resource. The species found in that area look for resources in the locale. Because they have a small body size, they require low amounts of food, beyond having short life cycles. This may facilitate their occurrence in the area. On the other hand, large dung beetles have the behaviour of burying fecal masses for food and reproduction. Probably they come from the small clumps of forest and/or conservation areas, making part of the local fauna of Scarabaeoidea. It is likely that these species could not to be established on this site, due to agricultural practices: constant soil tillage for the two main annual crops in Mato Grosso do Sul (corn and soybeans), and massive use of pesticides for insect pest control.

The pasture was the environment with the highest diversity, with more constant, very abundant and dominant species. This can be explained by increased supply and distribution for a longer and constant time with resource for the dung beetles (feces) in this ecosystem, reducing interspecific competition, but also due to the adaptability of the Scarabaeoidea to the modified environments. Because these beetles probably already inhabited the original environment, and other species that migrated to there in search of resources were added to the community.

The lowest level of diversity index was recorded in the forest. However, there was the largest number of unique species. This shows the importance of the presence of small areas of forests for biodiversity conservation, because they provide refuge sites.

The fragmentation or habitat alterations can induce changes in species richness and abundance of populations. 
It is possible that the beetle species have modified their habitats, migrate in search resource elsewhere and settled there. Small conservation areas or small clumps in the middle of large agricultural areas can serve as a refuge, avoid reproductive isolation between populations, facilitate the dispersal and connectivity between other ecosystems, and ensure the maintenance of species (Larsen et al., 2005). One of these aspects was evident in this research, since the largest number of native species was recorded in the forest area.

Dung beetles (Scarabaeoidea) are dependent on the excrement of macro-vertebrates, and their communities are influenced by changes in the communities of mammals and other animals (Hernández et al., 2003). Natural environments, like the surveyed forest reserve in this work, also favours the occurrence of natural enemies (parasitoids, predators and pathogens) of these beetles, keeping in check their populations.

In agricultural and forest environments, there were only two dominant, constant and very abundant species; being all others common (Table 1). This demonstrates that few species were actually living in that place, and probably the majority were there looking for resources (food, shelter and nesting sites).

Regarding the agricultural area, although this had presented higher abundance and a higher average number of individuals captured in positive traps, in relation to pasture and forest, environments with pasture and agriculture did not differ significantly from each other, and the area of forest had lower values in compare to the other two environments (Table 2).

The pattern found in the dung beetle fauna in the three environments evaluated in this study, suggests that there are few species unique to each environment, indicating that the community that occurred before the environmental change could be the same now, but with different attributes. Most of these species are still under the impact of changes in the natural environment. This impact results from the replacement of large areas of native flora by extensive areas of monocultures with high mechanisation.

In this paper, the greatest diversity of Scarabaeoidea obtained in the pasture is congruent with the results of Halffter (1991), suggesting that in the Neotropical region, grazing environments have a greater diversity of dung beetles. The diversity was higher where there was a greater supply in quantity and more regular temporal distribution of resources.

The results in this paper support the use of dung beetles as an indicator of biodiversity with implications for the type of land use in several annual crops. According to the approach by Rocha et al. (2010), dung beetles are considered good ecological bioindicators, because they present high species richness, diversity of habitats, they are easy to handle, ecologically faithful, fragile to small changes and their organisms respond. Also, Scarabaeidae could be good candidates for ecological monitoring in both kinds of landscapes: forest and agriculture environments. Bare soils are less available to dung beetles, because beyond erosion, the frequent exposure to wind and sunshine can makes them vulnerable, and consequently, the dryness and trampling by cattle may hinder the action of these Scarabaeoidea.

We conclude that the conservation of small remaining areas of forest is important, because the heterogeneity and conservation status of these environments enable the maintenance of some species of dung beetles, and consequently, their environmental services.

Acknowledgements - MMR wishes to thank his wife Verônica, and his sons: Thiago Américo, Franchescole, and Marino, for their help, care, love and understanding; Sergio Roberto Rodrigues for the help; Odival Faccenda for the help with the statistical analysis; Huberto Noroeste dos Santos Paschoalicki, for understanding the importance of this work; João Fernandes, Adão Campos, and Paulo Luciano de Souza, who allowed the survey on their property and helped in the collections. Also, we thank Irena Bevk (University of Ljubljana, Biotechnical Faculty, Ljubljana, Slovenia) for a review of the manuscript.

\section{References}

AYRES, M., AYRES JÚNIOR, M., AYRES, DL and SANTOS, AA., 2007. BIOESTAT 5.0 - Aplicações estatísticas nas áreas das ciências bio-médicas. Belém: OngMamiraua.

ANDERSEN, E., 2003. Effects of dung presence, dung amount, and secundary dispersal by dung Beetles on the fate of Micropholis guyanensis (Sapotaeae) seeds in Central Amazonia. Journal of Tropical Ecology, vol. 17, p. 61-78. http://dx.doi.org/10.1017/ S0266467401001043

Brasil. Ministério das Minas e Energia, Secretaria Geral. Projeto RADAMBRASIL, 1982. Geologia, geomorfologia, pedologia, vegetação e uso potencial da terra. Folha SF. 21 Campo Grande. p. 416.

COLWELL, RK., 2003. Estimate versão 700/2003. Available from: <http://viceroy.eeb.uconn.edu/Estimates7/EstimateS\%>. Access in: 23 Apr. 2008.

DURÃES, R., MARINS, WP. and VAZ-DE-MELLO, FZ., 2005. Dung Beetle (Coleoptera: Scarabaeidae) assemblages across a natural forest-cerrado ecotone in Minas Gerais, Brazil. Neotropical Entomology, vol. 34, p. 721-731. http://dx.doi.org/10.1590/ S1519-566X2005000500003

ENDRES, AA., CREÃO-DUARTE, AJ. and HERNÁNDEZ, MIM., 2007. Diversidade de Scarabaeidae s. str. (Coleoptera) da Reserva Biológica Guaribas, Mamanguape, Paraíba, Brasil: uma comparação entre Mata Atlântica e Tabuleiro Nordestino. Revista Brasileira de Entomologia, vol. 51, p. 67-71.

FLECHTMANN, CAH., RODRIGUES, SR. and COUTO HTZ., 1995. Controle biológico da mosca-dos-chifres (Haematobia irritans) em Selvíria, Mato Grosso do Sul. Revista Brasileira de Entomologia, vol. 39, p. 259-276.

FAVERO, S., SOUZA, HA. and OLIVEIRA, AKM., 2011. Coleoptera (Insecta) as Forest fragmentation indicators in the Rio Negro Sub-region of the Pantanal, Mato Grosso do Sul, Brazil. Brazilian Journal of Biology, vol. 71, p. 291-295. PMid:21537602. http://dx.doi.org/10.1590/S1519-69842011000200008

GANHO, NG. and MARINONI, RC., 2005. A diversidade de Coleoptera (Insecta) em uma paisagem antropizada do Bioma 
Araucária. Revista Brasileira de Entomologia, vol. 49, p. 535-543. http://dx.doi.org/10.1590/S0085-56262005000400014

HALFFTER, G., 1991. Historical and ecological factors determining the geographical distribution of beetles (Coleoptera: Scarabaeidae: Scarabaeinae). Folia Entomologica Mexicana, vol. 82, p. 195-238.

HALFFTER, G. and FAVILA, MH., 1993. The Scarabaeinae (Insecta : Coleoptera), an animal group for analyzing, inventorying and monitoring biodiversity in Tropical rainforest and modified landscapes. Biology International, vol. 27, p. 15-21.

HAMMER, O.; HARPER, DAT. And RYAN, PD, 2003. Paleontological Statistics-PAST. version 1.18. Available from: $<$ http://folk.uio.no/ohammer/past/>.

HANSKI, I. and CAMBEFORT, Y., 1991. Dung Beetles Ecology. Journal Animal Ecology, vol. 62, p. 396-397.

HERNÁNDEZ, B., MAES, JM., HARVEY, CA., VILCHEZ, S., MEDINA, A. and SÁNCHEZ, D., 2003. Abundancia y diversidad de escarabajos coprófagos y mariposas diurnas em um paisaje ganadero em El departamento de Rivas, Nicaragua. Agroforesteria em las Americas, vol. 10, p. 29-40.

HORGAN, FG. and FUENTES, RC., 2005. Asymmetrical competition between neotropical dung beetles and its consequences for assemblage structure. Ecological Entomology, vol. 30, p. 182-193. http://dx.doi.org/10.1111/j.0307-6946.2005.00673.x

HUGHER, RG., 1999. Theories and models of species abundances. The American Naturalist, vol. 128, p. 879-899.

KOLLER, WW., GOMES, A., RODRIGUES, SR., and GOIOZO, PFI., 2007. Scarabaeidae e Aphodiidae Coprófagos em Pastagem Cultivadas em Área do Cerrado Sul-mato-grossense. Revista Brasileira de Zoociência, vol. 9, p. 81-93.

KREBS, CJ., 1978. Ecology: The experimental analysis of distribution and abundance. New York: Harper \& Row. p. 678.

LARSEN, T., WILLIAMS, N. and KREMEN, C., 2005. Extinction order and altered community structure rapidly disrupt ecosystem functioning. Ecology Letters, vol. 8, p. 538-547. PMid:21352458. http://dx.doi.org/10.1111/j.1461-0248.2005.00749.x

LUMARET, JP. and KIRK, A., 1987. Ecology of dung Beetles in the French Mediterranean Region (Coleoptera : Scarabaeinae). Acta Zoologica Mexicana, vol. 24, p. 1-55.
MAGURRAN, AE., 1988. Ecological diversity and its measurement. Princeton: Princeton University Press. p. 179.

MALVA, I., HERNÁNDEZ, M. and VAZ-DE-MELLO, FZ., 2009. Sesonal and spatial species richness variation of dung beetle (Coleoptera, Scarabaeidae s. str.) in the AtlanticForest of southeasternBrazil. Revista Brasileira de Entomologia, vol. 53, p. 607-613. http://dx.doi.org/10.1590/S0085-56262009000400010

MARINONI, RC. and GANHO, NG., 2006. A diversidade diferencial beta de Coleoptera (Insecta) em uma paisagem antropizada do Bioma Araucária. Revista Brasileira de Entomologia, vol. 50, p. 64-71. http://dx.doi.org/10.1590/S0085-56262006000100009

NICHOLS, E., LARSEN, T., SPECTOR, S., DAVIS, AL., ESCOBAR, F., FAVILA, M. and VULINEC, K., 2007. Global dung beetle response to tropical forest modification and fragmentation: A quantitative literature review and meta-analysis. Biological Conservation, vol. 137, p. 1-19. http://dx.doi.org/10.1016/j. biocon.2007.01.023

QUINTERO, I. and ROSLIN, T., 2005. Rapid recovery of dung beetle communities following habitat fragmentation in Central Amazonia. Ecology, vol. 86, p. 3303-3311. http://dx.doi. org/10.1890/04-1960

RIDSDILL-SMITH, TJ., 1986. The effect of seasonal changes in cattle dung on egg production by two species of dung beetle (Coleoptera: Scarabaeidae) in South-Western Australia. Bulletin Entomological Research, vol. 76, p. 63-68. http://dx.doi.org/10.1017/ S0007485300015285

ROCHA, JRM., ALMEIDA, JR., LINS, GA and DURVAL, A., 2010. Insects as indicators of environmental changing and pollution: a review of appropriate species and their monitoring. Holos Environment, vol. 10, p. 250-262.

RODRIGUES, SR. and MARCHINI, LC., 2000. Ocorrência de besouros coprófagos em dois diferentes ambientes. Revista Brasileira de Entomologia, vol. 44, p. 35-38.

VULINEC, K., 2002. Dung beetle communities and seed dispersal in primary forest and disturbed land in Amazonia. Biotropical, vol. 34, p. 297-309.

WHITTAKER, RH., 1972. Evolution and measurement of species diversity. Taxon, vol. 21, p. 213-251. http://dx.doi. org/10.2307/1218190 